\title{
In Vitro Suppressive Effect of Agriculture Residues and Municipal Solid Wastes Compost Tea on some Phytopathogenic Fungi
}

\section{Gehan, A.E. Elsaiid ${ }^{1}$, Samia H. Abou zekry², Ehab, A.D. Sarhan³ ${ }^{3}$, Mehreshan T. El-Mokadem ${ }^{4}$, Abdel- Wahab, A.F.M. ${ }^{5}$,}

${ }^{1,2,4}$ Botany Dept., Faculty of Womenfor Arts, Science and Education, Ain Shams University.

${ }^{3}$ Plant Pathology Research Institute, Agricultural Research Center, Giza, Egypt.

${ }^{5}$ Agric. Microbiol. Dept., Soils, Water and Environ. Res. Inst., ARC, Giza, Egypt.

\begin{abstract}
Aerated Compost Tea (ACT) prepared from four types of compost; Agricultural Residues(AR), Agricultural Residues enriched with Olive Pomace (AR+OP), Municipal Solid Wastes (MSW) and Municipal Solid Wastes enriched with $\mathrm{OP}(\mathrm{MSW}+\mathrm{OP})$ in combination with bioagents have been analytically characterized and were tested for their antagonistic activity in vitro against Fusarium oxysporum and Rhizoctonia solani pathogens in comparison with the commercial chemical fungicides (Rhizolex-T). Assessment was carried out in terms of percent mycelial growth inhibition as well as Scanning Electron Microscopy (SEM) were used to explain the mode of action in the biological control of the pathogens under study. From the resultsall compost teas showed high levels of nutrients and microbial biomass content. The mixed treatment of compost tea gave the highest percent inhibition compared with individually treatments. AR compost tea+ Olive Pomace (OP)+ Microorganisms (MO) were significantly superior to the rest treatments showed $63.52 \%$ and $44.07 \%$ percent inhibition, same trend was detected with MSW+ Olive Pomace (OP)+ Microorganisms (MO) showing $57.41 \%$ and $43.89 \%$ against Rhizoctonia solani andFusarium oxysporumrespectively. SEM of tested pathogen mycelium removed from the confrontation zone showed aberrant morphology such as shrinkage, curling,mycelium asymmetry, partial distortions and lysis of fungal mycelium. In conclusion, these results provide evidence that the compost extract has the potential to become a good candidate for biological control as potential alternatives to the application of synthetic fungicides, and as plant promoters in crop production, for attaining environmental sustainability for farming and food safety.
\end{abstract}

Keywords : Compost, Compost tea, Bioagents, Olive pomace, $R$. solani, Rhizolex-T, Microorganisms (MO).

*Corresponding author: Gehan elbaz Email: gehanae@yahoo.com 


\section{Introduction:}

Compost tea are fermented extracts of composted materials carried out on liquid phase in commercial or rudimental brewers, for a few days or up to two weeks with or without active aeration (Scheuerell \& Mahaffee, 2002; Litterick et al., 2004; Ingham, 2005).Several studies have shown that compost and its liquid preparations actively enhances soil fertility, sustains productivity and provides efficient control of weed seeds and several plant pathogens (Joshi et al., 2009; Zaccardelli et al., 2011).In this regard, compost teas are viewed as potential alternatives to the use of the common synthetic fungicides in response to the increasing needs of environmental substainability for farming and food safety (El-Morsi \& Abdel-Monaim, 2015). Compost prepared from different feedstock varies considerably in chemical, physical and biotic composition and consequently vary in ability to suppress soil borne diseases (Castaño et al., 2011). So the amendments of specific microorganisms to compost are sometimes necessary, since the potential of compost to suppress plant disease is a highly variable phenomenon (Yang et al., 2011; Zhao et al., 2011; Huang et al., 2011).Yogen et al. (2006) and Khalil \& El-Maghrabia (2010) found that Compost and/or compost tea fortified with bio-control agents (bio-compost) when applied as soil amendments were able to reduce pathogens propagates density and protect plants from soil borne pathogens. Larger quantities of waste products associated with olive oil production are being disposed in the environment (olive leaves, olive pomace and olive mill waste water). In fact (Ergu et al., 2008) has proven that this Olive Pomace (OP) waste may potentially acts as good sources of plant nutrients and can be used as a soil conditioner/fertilizers amendments and proposed as one of the most suitable methods to restore soil fertility and resolve the problem of their disposal (Abu-Zreig \& Al-Widyan, 2002; Bonanomi et al., 2006). Also, the plant polyphenols can be used as natural plant protection agent exhibiting antimicrobial activity to control infestations of bacteria (Baydar et al., 2006) and fungi (Bruno and Sparapano, 2007).Based on these assumptions, the principle objective of the proposed study is to evaluate in vitro the bio-potential of two types of compost tea from different feedstock and enriched with OP and biocontrol agents as single treatments and/or in combination to suppress fungal diseases caused by Rhizoctonia solani and Fusarium oxysporum, as well as Scanning Electron Microscope (SEM) to evaluate antagonistic effect against fungal pathogens. Teas are characterized for physical, chemical, microbiological and phytotoxicity.

\section{Materials \& Methods:}

\subsection{Microbial Inoculum:-}

\subsubsection{Phytopathogenic fungi:-}

Two lentil(Lens culinaris, Medik.) Pathogens;Rhizoctonia solani and Fusarium oxysporum f. sp. lentis were provided by legume and forgae diseases research department, Plant Pathology Research Institut, ARC, Giza, Egypt.Pathogenic fungi were isolated from naturally infested lentil stem showing damping - off and wilt disease. The fungus were regularly sub-cultured and maintained on potato dextrose agar (PDA) mediumin a refrigerator at $5 \pm 1{ }^{\circ} \mathrm{C}$ until use. 


\subsubsection{Bioagents:-}

Bacterial strains (Pseudomonas fluorescens (IFO.2034), Serratia marcescens (WW4) and Paenibacillus polymyxa (local isolate of rhizobacteria) inoculants) and fungal strains (Trichoderma harzianumand Trichoderma virdie)were supplied by Microbiology Dept., Soils, Water and Environment Research Institute, Agricultural Research Center (ARC), Giza, Egypt.Pseudomonas was grown on king's medium (Atlas, 1995),Serratia sp. was grown on peptone glycerol (Difco Manual, 1984),Bacillus polymyxa wasgrown on nutrient broth medium (Difco Manual, 1984)and Trichoderma sp grown on Trichoderma selective (TSM) broth medium (Askew and Laing 1993)was developed by (El-Hassan, 2004).Cultures were incubated at $28^{\circ} \mathrm{C}$ until early log phase reached $10^{9}$ viable cell $\mathrm{ml}^{-1}$ and were mixed in equal proportion to prepare 1 liter of concentrate containing $10^{9} \mathrm{cell} \mathrm{ml}^{-1}$.

\subsection{Initial Compost and Compost tea preparation:-}

Two types of compost under study; Agricultural Residues (AR) was provided from Ismaillia Agricultural Research Station, Ismaillia Governorate, Egypt while the other from Municipal Solid Wastes (MSW) was provided from Qatameia, Cairo, Egypt composting and recycling complex, Delta Biotec. Both types were enriched with olive pomace (10\%); the Raw Olive Pomace (ROP) was air dried at $30^{\circ} \mathrm{C}$ for 24 hours then ground to $0.5 \mathrm{~mm}$ by using ball mill and sieved to reduce the materials to fine particles. The mixtures are moistened to the appropriate degree (50-60\%), and then both types were leaved for 21 days incubation period with frequentturning every week and following the humidity. At the end of the period of incubation, a complete analysis of the physical, chemical and microbiological characters was done. The main traits of composts and enriched compost with olive pomace are shown in Table (1).

Aerated compost tea was prepared from matured compost before and after enrichment with Olive Pomace (OP). The compost tea were prepared according to (Abdel-Wahab, 2008; Naidu et al., 2010). After elapsing of incubation period andbefore application, fulvic acid is added $(25 \mathrm{ml})$, the liquid mixture was filtered through cheese clothes and stored at $4^{0} \mathrm{C}$; they were taken out 30 minutes before use (Znaidi, 2002). The bioagents mixtures were added to the freshly prepared compost tea according to (Abdel-Wahab, 2008) (compost tea act as a liquid carrier). The microbial enriched compost tea was maintained up to 3 days before application.

\subsection{Analysis of compost teas:-}

The chemical and microbiologicalanalytical characters as well as maturity and stability index of compost teas were recorded at the end of the fermentation period; physical characters were detected according to (Jimenez \& Garcia, 1989). Chemical properties were determined according to (Page et al., 1982). Extinction coefficient $\left(\mathrm{E}_{4} / \mathrm{E}_{6}\right)$ ratio was measured according to (Page et al., 1982), where $E_{4}$ and $E_{6}$ are the optical densities at 465 and $665 \mathrm{~nm}$ wavelengths, respectively. 
Total phenolics were determined by the method of (Singleton \& Rossi, 1965).Total count of mesophilic bacteria, fungi, and actinomycetes were determined using nutrient agar, Martin's media, and Jensen media, respectively and the plate count techniques method according to (Page et al., 1982).Dehydrogenase activity was assayed according to the (Casida et al., 1964). Phytotoxicity test was assayed using cress seeds (Lepidium stavium L.) to evaluate compost maturity and stability according to (Pare et al., 1997).

\subsection{In vitro test of antifungal activity of compost extract:-}

The antifungal effect of the aqueous olive pomace extract, bioagent mixture, commercial fungicides and different types of compost teas on the linear growth of the tested fungi was studied in vitro by a poisoned food technique (Agarwal et al., 2001).

Table (1): Main characteristics of solid composts used to produce compost teas by aerated fermentation.

\begin{tabular}{|c|c|c|c|c|}
\hline Property & $\mathbf{A R}$ & $\begin{array}{c}\mathbf{A R}+ \\
\text { OP }\end{array}$ & MSW & $\begin{array}{c}\text { MSW } \\
+ \text { OP }\end{array}$ \\
\hline Water holding capacity (\%) & 150.7 & 120 & 143.2 & 130 \\
\hline pH (1:10 extract) & 7.1 & 7.7 & 8.10 & 8.3 \\
\hline $\mathrm{EC}(\mathrm{dS} / \mathrm{m})$ & 3.5 & 5.04 & 7.4 & 6.9 \\
\hline Organic carbon (\%) & 18.72 & 19.8 & 17.95 & 18.3 \\
\hline Organic matter $(\%)$ & 32.27 & 34.1 & 30.95 & 31.5 \\
\hline Total- N (\%) & 1.5 & 1.6 & 0.8 & 0.9 \\
\hline C/N ratio & 12.6 & 12.36 & 22.58 & 20.98 \\
\hline Available-P $\left(\mathrm{mgKg}^{-1}\right)$ & 356.8 & 315.4 & 296.97 & 282.6 \\
\hline Available-K $\left(\mathrm{mgKg}^{-1}\right)$ & 647.1 & 748 & 667.7 & 759.9 \\
\hline Available $\mathrm{Fe}\left(\mathrm{mgKg}^{-1}\right)$ & 175.7 & 181.07 & 278.7 & 363.67 \\
\hline Available Mn $\left(\mathrm{mgKg}^{-1}\right)$ & 32.5 & 37.9 & 69.9 & 71.6 \\
\hline Available $\mathrm{Cu}\left(\mathrm{mgKg}^{-1}\right)$ & 3.73 & 5.0 & 32.0 & 46.53 \\
\hline Available $\mathrm{Zn}\left(\mathrm{mgKg}^{-1}\right)$ & 31.37 & 33.77 & 103.87 & 121.53 \\
\hline CEC (c mol/Kg) & 117.8 & 120 & 106.8 & 113.7 \\
\hline Total Phenol content (\%) & 0.4 & 0.50 & 0.70 & 0.6 \\
\hline Total count of Bacteria $(\mathrm{cfu} / \mathrm{g})$ & $3.8 \times 10^{8}$ & $5 \times 10^{8}$ & $2.7 \times 10^{8}$ & $4.7 \times 10^{8}$ \\
\hline Total count of Fungi(cfu/g) & $6 \times 10^{6}$ & $8.1 \times 10^{6}$ & $5.8 \times 10^{6}$ & $6.3 \times 10^{6}$ \\
\hline Total count of Actinomycetes (cfu/g) & $2.5 \times 10^{6}$ & $4 \times 10^{6}$ & $3 \times 10^{6}$ & $4 \times 10^{6}$ \\
\hline E.coli count & Nil & Nil & Nil & Nil \\
\hline Salmonella \& Shigella & Nil & Nil & Nil & Nil \\
\hline Dehydrogenase activity $\left(\mu \mathrm{gTPF}^{*} / \mathrm{g}\right)$ & 120.8 & 140.1 & 119.7 & 129 \\
\hline
\end{tabular}

*Tri-Phenyl-Formazan.

In case of OP, 10 gram was dissolved in $100 \mathrm{ml}$ water, and then were filtered and mixed with molted sterile potato dextrose agar medium (PDA) to obtain the proposed concentration of $10 \%$ 
(v/v). Regarding fungicide;Rhizolex-T was incorporated into sterilized PDA medium after cooling to obtain final concentrations of $1,5,10$ and $25 \mathrm{ppm}$. The medium was then poured intopetri-dishes, while in case of bioagents mixture and compost tea; $10 \mathrm{ml}$ was incorporated into sterilized PDA medium after cooling. The medium was then poured into petri-dishes (with three replicates for each treatment), and untreated PDA medium was used as control.After solidification of the medium each plate was inoculated centrally with a mycelial disc $(5 \mathrm{~mm}$ diameter) taken from the outer margins of actively growing mycelium from PDA cultures of each

isolate by sterile cork borer. Plates were incubated at $28 \pm 2^{0} \mathrm{C}$ and colony diameters were measured after 5days(Mahmoud, 2000). When the untreated control had just covered the plate Percentage of inhibition was calculated using the following formula (Perveen \& bokhari, 2012).

Percentage of growth inhibition $=(\mathrm{C}-\mathrm{T}) / \mathrm{C} \times 100$

Where, $\mathrm{C}=$ average of three replicates of hyphal growth $(\mathrm{cm})$ of test fungus in control plate and $\mathrm{T}=$ average of three replicates of hyphal growth $(\mathrm{cm})$ of the same test fungus in plates treated with the tested material.

\subsection{Evaluation of morphological changes via Scanning Electron Microscopy (SEM):-}

Blocks of the investigated fungal isolate were prepared for SEM at The Regional Center for Mycology and Biotechnology, Al-Azhar Univ.. Fixation and dehydration procedures were performed using the programmable LEICA EM TP tissue processor model (A-1170), Specimens were then gold-coated (nearly $50 \mathrm{~nm}$ thickness) using an SPI ModuleTMSputter Coater and then examined using the high-vacuum mode of a JEOL JSM-5500LV Scanning Electron Microscope. Energy-dispersive X-ray spectroscopy $(\mathrm{EDX})($ Elad et al., 1983).

\subsection{Statistical analysis:-}

The obtained data were subjected to an analysis of variance (ANOVA) according to (Gomez $\boldsymbol{\&}$ Gomez, 1984).

\section{Result:-}

\subsection{Physico-chemical and microbiological analysis of compost tea:-}

\subsubsection{Physico-chemical determinants:-}

Chemical characteristics are shown in Tables (2), after brewing period, the $\mathrm{pH}$ of four types recorded 6.92, 7.41, 7.12 and 8.05 for AR, AR+OP, MSW and MSW+OP, while in case of EC, it recorded $2.50 \mathrm{ds} / \mathrm{m}, 3.30 \mathrm{ds} / \mathrm{m}, \mathbf{6 . 6 2} \mathrm{ds} / \mathrm{m}$ and $\mathbf{6 . 3 3} \mathrm{ds} / \mathrm{m}$ for $\mathrm{AR}, \mathrm{AR}+\mathrm{OP}, \mathrm{MSW}$ and MSW+OP respectively.

Concerning nutrients and micronutrientscomposition; including organic carbon (OC), organic matter $(\mathrm{OM})$, nitrogen $(\mathrm{N})$, phosphorus $(\mathrm{P})$, potassium $(\mathrm{K})$ and micronutrients: iron $(\mathrm{Fe})$, manganese $(\mathrm{Mn})$, copper $(\mathrm{Cu})$ and zinc $(\mathrm{Zn})$ were significantly higher in olive pomace-enriched 
compost tea (CT) as compared tocompost tea alone, except for phosphorus, olive pomaceenriched CT exhibit lower values than compost teas alone.

Regarding $\mathrm{E}_{4} / \mathrm{E}_{6}$ ratio, four types of compost teas exhibit low values; they recorded 2.46nm, 2.49nm, 3.67nm and 3.21nm for AR, AR+OP, MSW and MSW+OP respectively.

\subsubsection{Microbiological assays:-}

Microbial populations in the produced Aerated Compost Tea (ACT) are shown in table (2), Culturable microbial population densities were significantly different from the initial compost materials illustrated in table (1).They were predominantly bacteria, the average of their densities increased in thefour types of compost teas after five days of brewing. The numbers of total aerobic bacteria were the highest among other microbial groups, such number is well appropriate for offering the treated plants with enough microbial coverage for pathogen suppression.Highest population density of culturable bacteria recorded10 $\times 10^{\mathbf{8}} \mathrm{cfu} / \mathrm{ml}$ in both mixture of $\mathrm{AR}$ compost tea and $\mathrm{AR}+\mathrm{OP}$ compost tea. However, fungal population densities were lower than those of bacteria and increased in all compost teas after five days of incubation. The highest population density of fungi was recorded $9 \times \mathbf{1 0}^{\mathbf{6}} \mathrm{cfu} / \mathrm{ml}$ in AR compost tea and $\mathbf{8 . 5} \times \mathbf{1 0}^{6} \mathrm{cfu} / \mathrm{ml}$ in $\mathrm{AR}+\mathrm{OP}$ compost teaof incubation. On the other hand, actinomycetes were the lowest group in all treatments. The Dehydrogenase activity (DHA-ase) was a very reliable indicator of global metabolic activity of the organisms inhabiting the compost teas. Data presented in table (2) shows that four types of compost tea recorded high value of dehyrogenase activities; they recorded 133.6, 125, 131.8 and $130 \mu \mathrm{g} T P F / 100 \mathrm{ml} / 24 \mathrm{hr}$ for AR, AR+OP, MSW and MSW+OP respectively.

Germination Index (GI) is the best way to test the phytotoxicity of compost to plant growth. They are widely used to test for salinity, soil pathogens, toxic substances (such as phenolic compounds, high ammonia concentration and heavy metals) and some chemical properties of compost which could be the major potential reasons of phytotoxicity. Data presented in table (2) shows that four types of compost tea recorded high Seed Germination (SG) and Root Growth $(\mathrm{RG})$ values, their Germination Index (GI) values were $>80 \%$.

Table (2): physico-chemical and microbiological traits of the prepared compost teas.

\begin{tabular}{|l|l|l|l|l|}
\hline \multicolumn{1}{|c|}{ Parameters } & \multicolumn{1}{|c|}{$\begin{array}{c}\text { AR compost } \\
\text { tea }\end{array}$} & AR+OP compost tea & MSW compost tea & \multicolumn{1}{|c|}{$\begin{array}{c}\text { MSW+OPcompost } \\
\text { tea }\end{array}$} \\
\hline pH & $\mathbf{6 . 9 2} \pm 0.14 \mathrm{c}$ & $\mathbf{7 . 4 1} \pm 0.29 \mathrm{~b}$ & $\mathbf{7 . 1 2} \pm 0.05 \mathrm{bc}$ & $\mathbf{8 . 0 5} \pm 0.13 \mathrm{a}$ \\
\hline EC $\left(\mathbf{d S m}^{-1}\right.$ at $\left.^{\mathbf{0}} \mathbf{C}\right)$ & $\mathbf{2 . 5 0} \pm 0.20 \mathrm{c}$ & $\mathbf{3 . 3 0} \pm 0.40 \mathrm{~b}$ & $\mathbf{6 . 6 2} \pm 0.58 \mathrm{a}$ & $\mathbf{6 . 3 3} \pm 0.30 \mathrm{a}$ \\
\hline Organic carbon $(\boldsymbol{\%})$ & $\mathbf{5 . 3} \pm 0.16 \mathrm{~b}$ & $\mathbf{7 . 0} \pm 0.46 \mathrm{a}$ & $\mathbf{4 . 7} \pm 0.26 \mathrm{~b}$ & $\mathbf{5 . 3} \pm 0.79 \mathrm{~b}$ \\
\hline Total- N $(\mathbf{p p m})$ & $\mathbf{8 0 . 1 4} \pm 0.71 \mathrm{~d}$ & $\mathbf{8 7} \pm 3.00 \mathrm{c}$ & $\mathbf{1 0 3 . 2} \pm 3.37 \mathrm{~b}$ & $\mathbf{1 3 9} \pm 2.00 \mathrm{a}$ \\
\hline Organic matter $(\%)$ & $\mathbf{9 . 1 4} \pm 1.04 \mathrm{~b}$ & $\mathbf{1 2 . 0} \pm 0.76 \mathrm{a}$ & $\mathbf{8 . 1 0} \pm 0.44 \mathrm{~b}$ & $\mathbf{9 . 1 4} \pm 0.38 \mathrm{~b}$ \\
\hline Available-P $(\mathbf{p p m})$ & $\mathbf{5 8 . 3 0} \pm 1.61 \mathrm{a}$ & $\mathbf{5 7 . 0} \pm 3.00 \mathrm{a}$ & $\mathbf{4 7 . 0 3} \pm 1.79 \mathrm{~b}$ & $\mathbf{3 4 . 1} \pm 1.32 \mathrm{c}$ \\
\hline Available-K $(\mathbf{p p m})$ & $\mathbf{2 5 3 . 6} \pm 3.14 \mathrm{~d}$ & $\mathbf{4 6 0} \pm 13.23 \mathrm{a}$ & $\mathbf{2 8 1 . 8} \pm 6.01 \mathrm{c}$ & $\mathbf{3 9 1} \pm 7.65 \mathrm{~b}$ \\
\hline Extractable- Fe $(\mathbf{p p m})$ & $\mathbf{1 2 . 9} \pm 0.10 \mathrm{~b}$ & $\mathbf{1 5 . 0} \pm 2.00 \mathrm{~b}$ & $\mathbf{1 7 . 5} \pm 0.56 \mathrm{a}$ & $\mathbf{1 8 . 3} \pm 1.47 \mathrm{a}$ \\
\hline
\end{tabular}


J. Sci. Res. Sci.,Vol.(35), 2018

\begin{tabular}{|c|c|c|c|c|}
\hline Extractable- Mn (ppm) & $\mathbf{3 . 0} \pm 0.26 \mathbf{c}$ & 10.2 $\pm 0.82 \mathrm{ab}$ & $9.6 \pm 0.40 \mathrm{~b}$ & $\mathbf{1 2 . 0} \pm 1.73 \mathrm{a}$ \\
\hline Extractable- Cu (ppm) & $3.5 \pm 0.46 \mathrm{c}$ & $4.0 \pm 0.50 \mathrm{c}$ & $8.6 \pm 0.95 b$ & $\mathbf{1 5 . 0} \pm 1.25 \mathrm{a}$ \\
\hline Extractable- Zn (ppm) & $3.94 \pm 0.20 \mathrm{c}$ & $4.5 \pm 0.50 \mathrm{c}$ & $9.2 \pm 0.72 b$ & $\mathbf{1 2 . 0} \pm 1.80 \mathrm{a}$ \\
\hline $\mathbf{E}_{4} / \mathbf{E}_{6}$ ratio & $\mathbf{2 . 4 6} \pm 0.10 \mathrm{c}$ & $2.49 \pm 0.06 \mathrm{c}$ & $\mathbf{3 . 6 7} \pm 0.12 \mathrm{a}$ & $\mathbf{3 . 2 1} \pm 0.25 \mathrm{~b}$ \\
\hline $\begin{array}{l}\text { Total count of Bacteria } \\
\left(\mathrm{cfu} \mathrm{ml}^{-1}\right)\end{array}$ & $\mathbf{1 0} \times 10^{8} \pm 1.00 \mathbf{a}$ & $10 \times 10^{8} \pm 0.05 \mathrm{a}$ & $\mathbf{9} \times \mathbf{1 0}^{8} \pm 0.14 \mathrm{a}$ & $\mathbf{7 \times 1 0 ^ { 8 } \pm 0 . 0 5 a}$ \\
\hline $\begin{array}{l}\text { Total count of Fungi (cfu } \\
\mathrm{ml}^{-1} \text { ) }\end{array}$ & $9 \times 10^{6} \pm 0.09$ a & $\mathbf{8 . 5} \times \mathbf{1 0}^{6} \pm 0.05 \mathrm{a}$ & $\mathbf{8} \times \mathbf{1 0}^{\mathbf{6}} \pm 0.04 \mathrm{a}$ & $\mathbf{7 \times 1 0 ^ { 6 } \pm 0 . 0 5 a}$ \\
\hline $\begin{array}{l}\text { Total count of } \\
\text { Actinomycetes }\left(\mathrm{cfu} \mathrm{ml}^{-1}\right)\end{array}$ & $\mathbf{4} \times 10^{6} \pm 0.18 \mathbf{a}$ & $\mathbf{4 \times 1 0 ^ { 6 }} \pm 0.05 \mathrm{a}$ & $\mathbf{5} \times \mathbf{1 0}^{\mathbf{6}} \pm 0.19 \mathrm{a}$ & $\mathbf{4 \times 1 0 ^ { 6 } \pm 0 . 1 3 a}$ \\
\hline $\begin{array}{l}\text { Dehydrogenase activity (mg } \\
\left.\mathrm{TPF}^{* *} / \mathrm{ml} / 24 \mathrm{hr}\right)\end{array}$ & $133.6 \pm 2.33$ a & $\mathbf{1 2 5} \pm 2.00 \mathrm{~b}$ & 131.8 $\pm 2.03 \mathrm{a}$ & $130 \pm 2.00 \mathrm{a}$ \\
\hline $\begin{array}{l}\text { Germination test of cress } \\
\text { seeds }\end{array}$ & $93.4 \pm 2.19 \mathbf{a}$ & $92 \pm 2.65 \mathbf{a b}$ & $87 \pm 2.65 \mathrm{c}$ & $89 \pm 1.00 \mathrm{bc}$ \\
\hline
\end{tabular}

\subsection{In vitro suppressiveness ofphytopathogens:-}

In vitro test were done to evaluate the efficacy of some botanical biocides (Aerated Compost Tea (ACT) prepared from four different types of compost, olive pomace extract, mixture of bioagents and their combination), compared with the standard synthetic fungicide (Rhizolex-T) against two soil-borne lentil crop pathogens (Rhizoctonia solani and Fusarium oxysporum).

Table (3): in vitro growth reduction (\%) of Rhizoctonia solani and Fusarium oxysporum in response to compost teas, bioagents mixture, $\mathrm{OP}$ and their combinations..

\begin{tabular}{|c|c|c|}
\hline \multirow[b]{2}{*}{ Treatment } & \multicolumn{2}{|c|}{ Mycelial growth percentage inhibition (\%) } \\
\hline & Rhizoctonia solani & Fusarium oxysporum \\
\hline Olive pomace & $46.67 \pm 2.23 \mathrm{~b}$ & $55.00 \pm 1.47 \mathrm{a}$ \\
\hline Bioagents mixture & $35.74 \pm 5.01 \mathrm{c}$ & $28.70 \pm 4.66 \mathrm{c}$ \\
\hline $\mathbf{A R}(\mathbf{C T})$ & $41.67 \pm 2.78 \mathrm{bc}$ & $25.22 \pm 0.30 \mathrm{c}$ \\
\hline MSW (CT) & $33.70 \pm 3.35 \mathrm{c}$ & $30.37 \pm 0.85 c$ \\
\hline AR+MO & $61.11 \pm 8.33 \mathrm{a}$ & $30.19 \pm 1.16 \mathrm{c}$ \\
\hline MSW+MO & $34.26 \pm 1.61 \mathrm{c}$ & $39.26 \pm 3.16 b$ \\
\hline $\mathrm{AR+OP}$ & $62.96 \pm 12.53 \mathrm{a}$ & $30.56 \pm 3.34 \mathrm{c}$ \\
\hline MSW+OP & $38.89 \pm 4.81 \mathrm{bc}$ & $41.48 \pm 4.02 \mathrm{~b}$ \\
\hline $\mathrm{AR}+\mathrm{OP}+\mathrm{MO}$ & $63.52 \pm 4.53 \mathrm{a}$ & $44.07 \pm 4.46 \mathrm{~b}$ \\
\hline $\mathrm{MSW}+\mathrm{OP}+\mathrm{MO}$ & $57.41 \pm 4.24 a$ & $43.89 \pm 2.78 \mathrm{~b}$ \\
\hline Control & $00.00 \mathrm{~d}$ & $00.00 \mathrm{~d}$ \\
\hline \multicolumn{3}{|l|}{ Fungicides } \\
\hline 1 ppm & $83.70 \pm 5.01 \mathrm{~b}$ & $5.80 \pm 0.14 \mathrm{~d}$ \\
\hline 5 ppm & $100.00 \pm 0.00 \mathrm{a}$ & $12.01 \pm 1.43 \mathrm{c}$ \\
\hline 10 ppm & $100.00 \pm 0.00 \mathrm{a}$ & $17.81 \pm 2.35 b$ \\
\hline 25 ppm & $100.00 \pm 0.00 \mathrm{a}$ & $37.47 \pm 1.90 \mathrm{a}$ \\
\hline
\end{tabular}

*each value represents the mean of three replicates. Values within a column followed by the same letter are not significantly different according to Duncan's multiple range test $(p=0.01)$ (1995). 
Treatment with compost tea, as a biological control approach, is a potential method to reduce the growth of pathogenic fungi. Data in table (3) indicate that all treatments in this study produced suppressive effect against the two soil borne pathogens. In fact, they inhibited $R$. solani mycelia growth more than $F$. oxysporum. Enrichment of compost with OPand microorganisms were the most effective treatments recorded63.52\% and $57.41 \%$ for $R$. solani while recorded $44.07 \%$ and $43.89 \%$ for $F$. oxysporum in case of $\mathrm{AR}+\mathrm{OP}+\mathrm{MO}$ and $\mathrm{MSW}+\mathrm{OP}+\mathrm{MO}$ respectively.

Regarding fungicides, four different concentrations of Rhizolex-T (1, 5, 10 and 25 ppm) were tested,table (3) reveal that the reduction in the growth of both tested fungi were correlated with increasing the commercial antifungal concentration(Rhizolex-T) in the medium. Data also indicate that both tested fungi varied in their sensitivity against the fungicides used.Rhizoctonia solanishowed more positive response than Fusarium oxysporum, complete growth inhibition was recorded for Rhizoctonia solani at 5, 10 and $25 \mathrm{ppm}$, while in case of Fusarium oxysporum the growth inhibition increase from $(\mathbf{5 . 8 3} \%$ to $\mathbf{3 7 . 5 2} \%)$ with increasing the concentration of Rhizolex-T from (1 to $25 \mathrm{ppm}$ ).
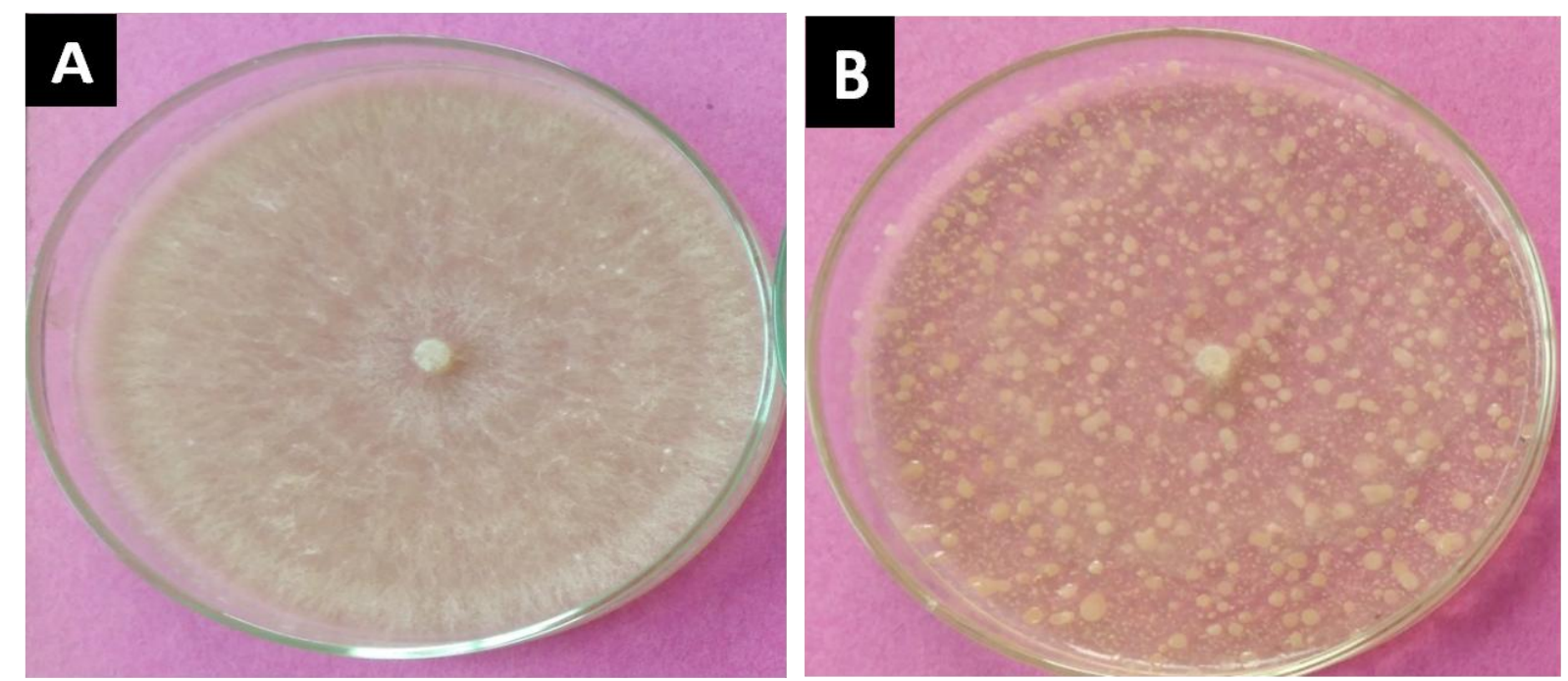

Photo 1: Effect of AR compost tea plus OP and bioagents on linear growth of $R$. solani. 1 (A)control; 1 (B) AR+OP+MO. 

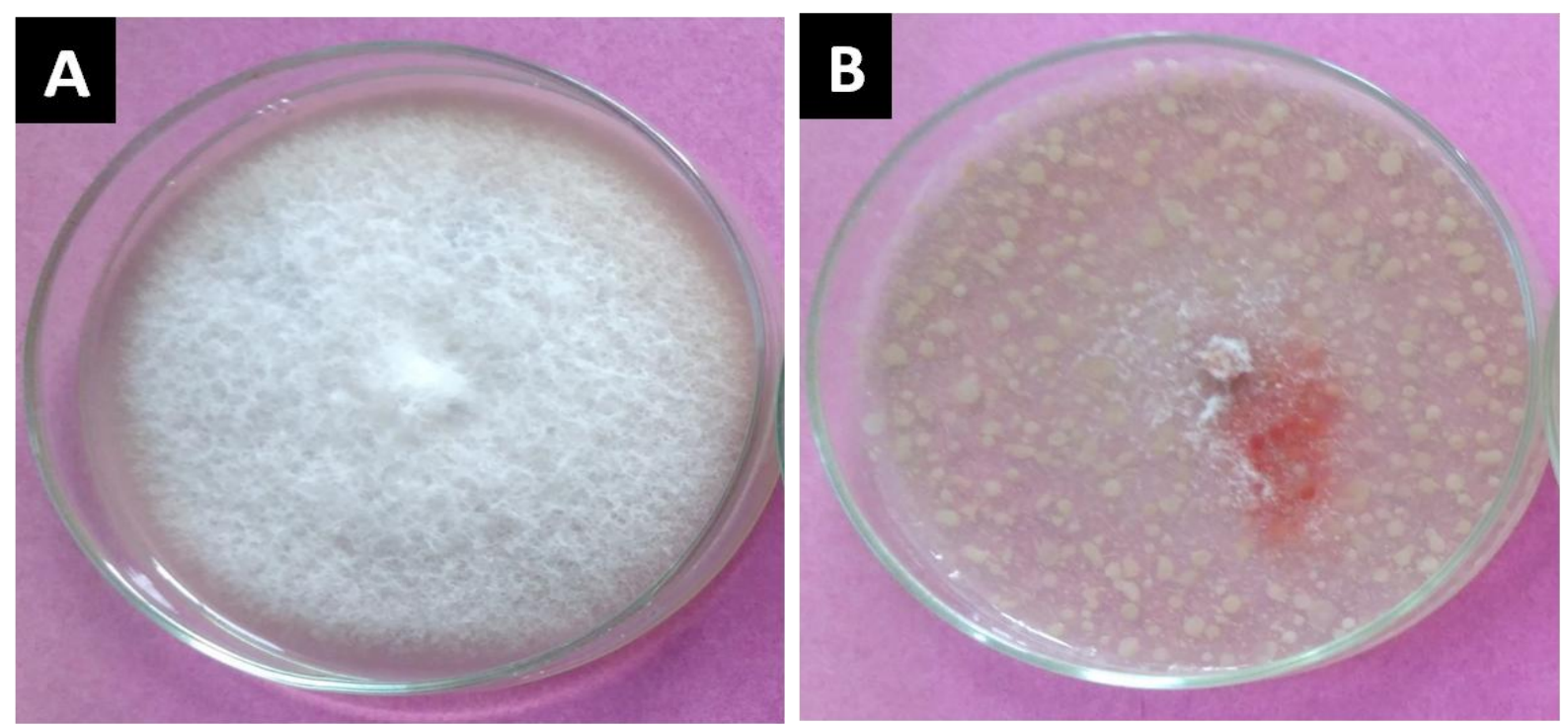

Photo 2: Effect of AR compost tea plus OP and bioagents on linear growth of $F$. oxysporum. 2 (A) control; 2(B) AR+OP+Mo.

\subsection{SEM effects of Compost tea on phytopathogens:-}

The use of electron microscopy facilitated the study of the mode of antagonistic action. Mycelial samples from the interaction region of the highest affected treatment.SEM clearly demonstrated changes in the morphology of bothpathogens in media containing the treatment (AR compost tea+OP+MO) extract.SEM observations of untreated (control) mycelia of $R$. solaniare illustrated in Photo3(A).Showinglong, even, and round hyphaewith typical tapered apices and a smooth surface.

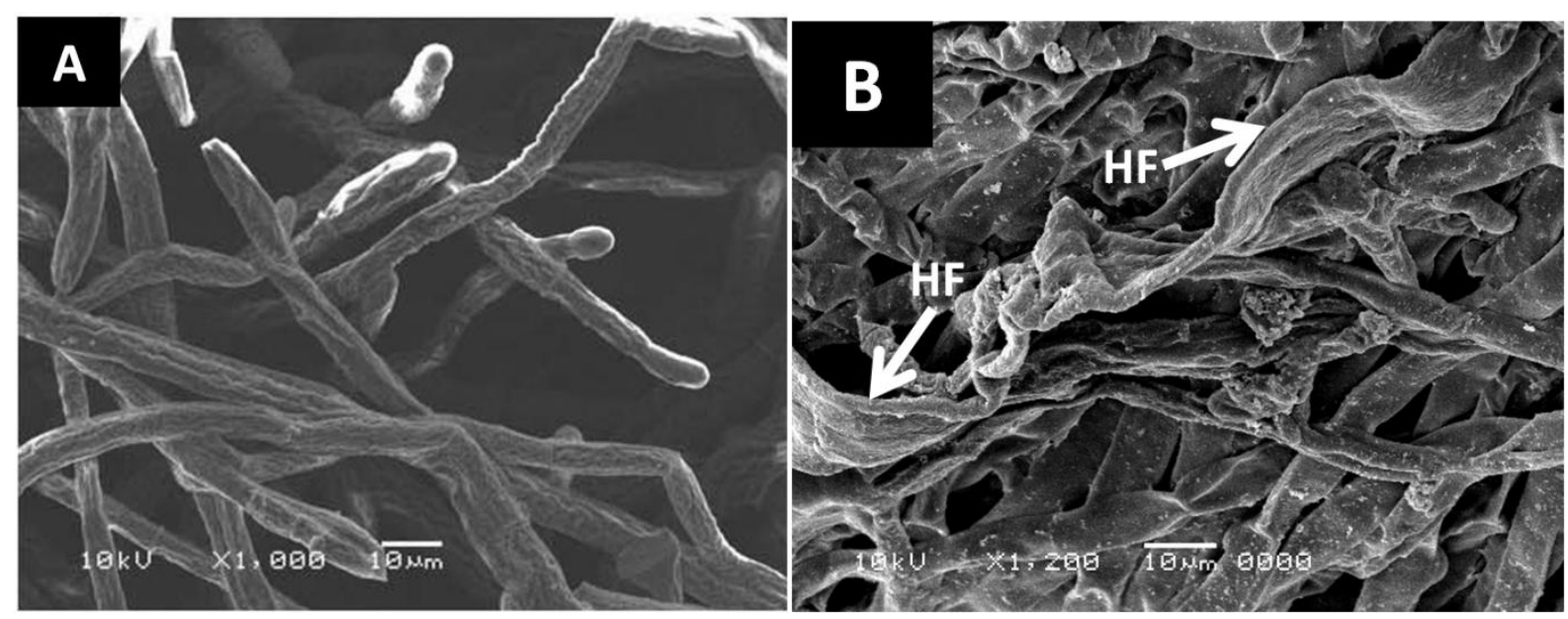




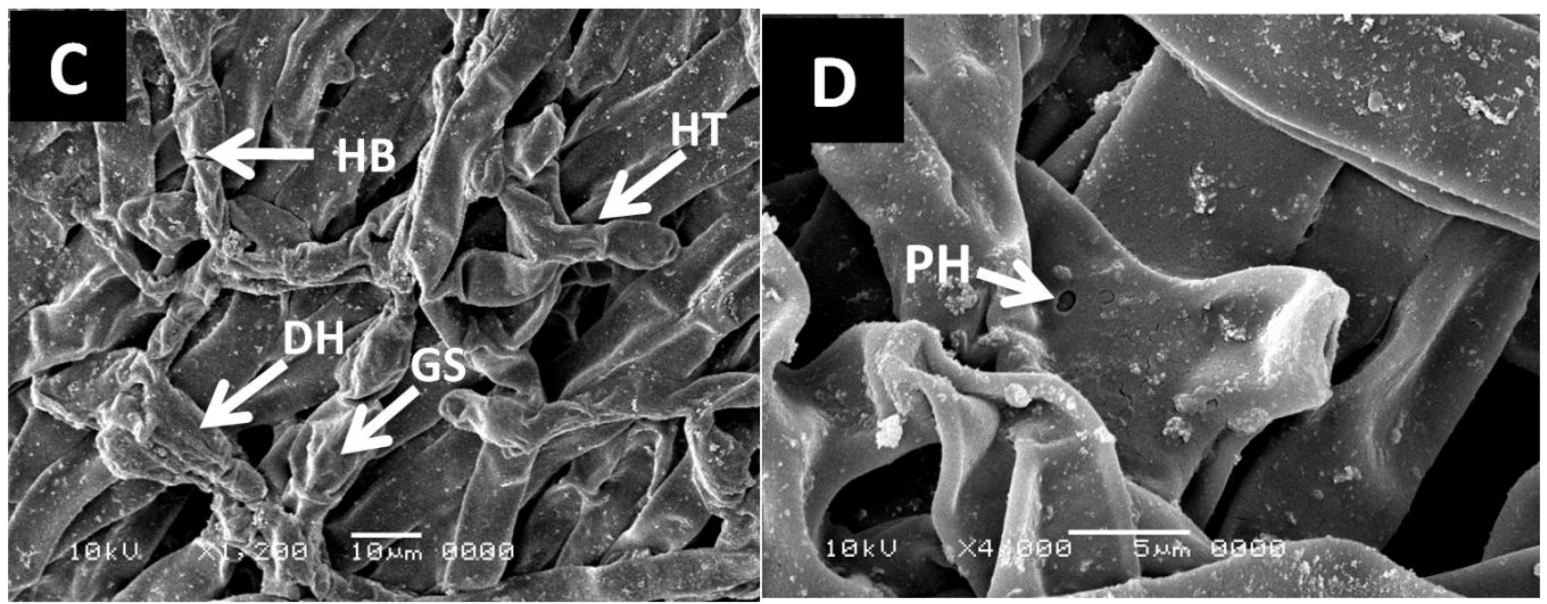

Photo 3(A, B, C and D) - SEM Micrographs of $R$. solani at x1000, x1200 and x4000. Long, even and round hypha shown in untreated ones photo 3 (A).Photos 3 (B, C and D)Showing treated hyphae culture; $R$. solani following treatment showhyphal fusion (HF), distorted hyphae (DH) and breakdown (HB) Photo3(B andC), treated culture are generally characterized by curling and twisting (HT), Photo 3 (D) penetration hole (PH).globular structures (GS) of various sizes along the surface of the mycelia Photo 3(C).

After treatment with the tested extract, Photo 3 (B, C and D), the prominent morphological changes appeared; sparse and asymmetric mycelium, hyphal swelling, curling (HT), rough cells with wrinkle cell along the surface of the mycelia and cell distortion (DH). The integrity of the cell surface of $R$. solani began to disintegrate, pronounced collapse and loss of turgor of $R$. solani hyphae were among the typical features of advanced alteration observed with signs of cell wall breakdown and destruction (HB). Additionally, fusion among the hyphae (HF) was observed.Close up SEM examination of $R$. solani at $(\times 4000)$ show evidence of penetration holes $(\mathrm{PH})$ and extensive cell damage.
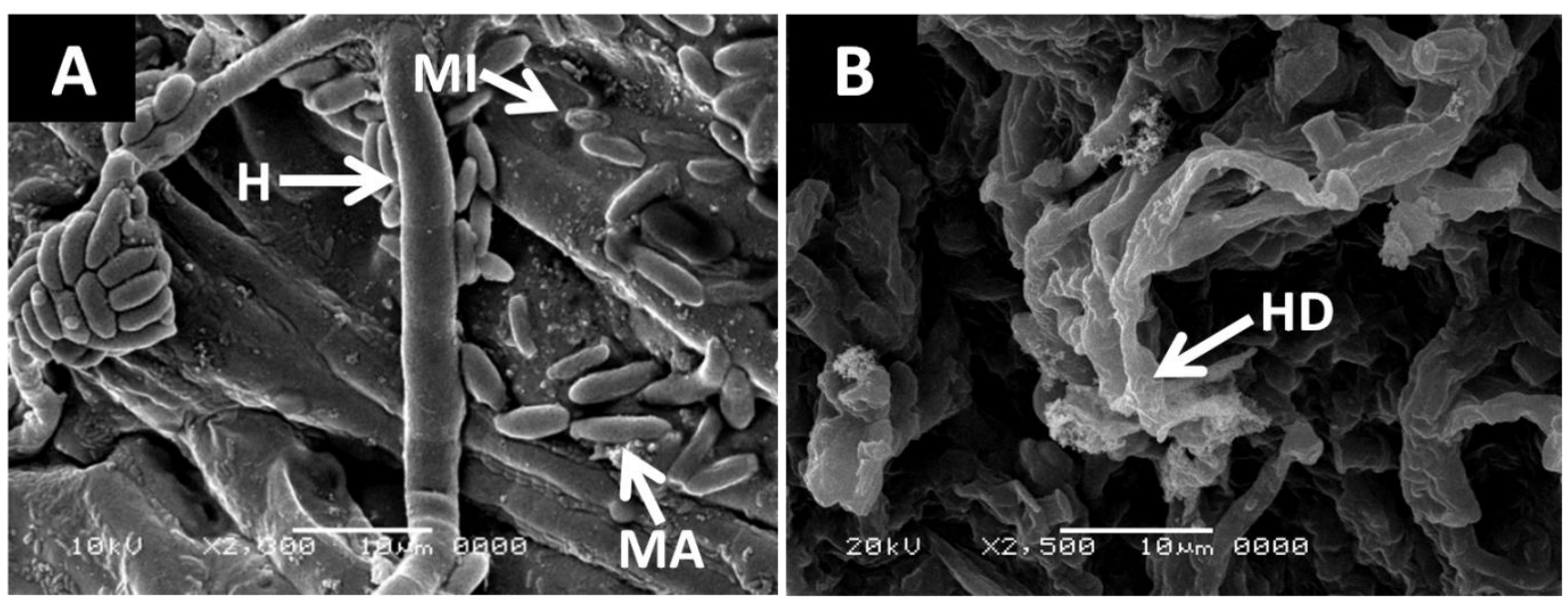

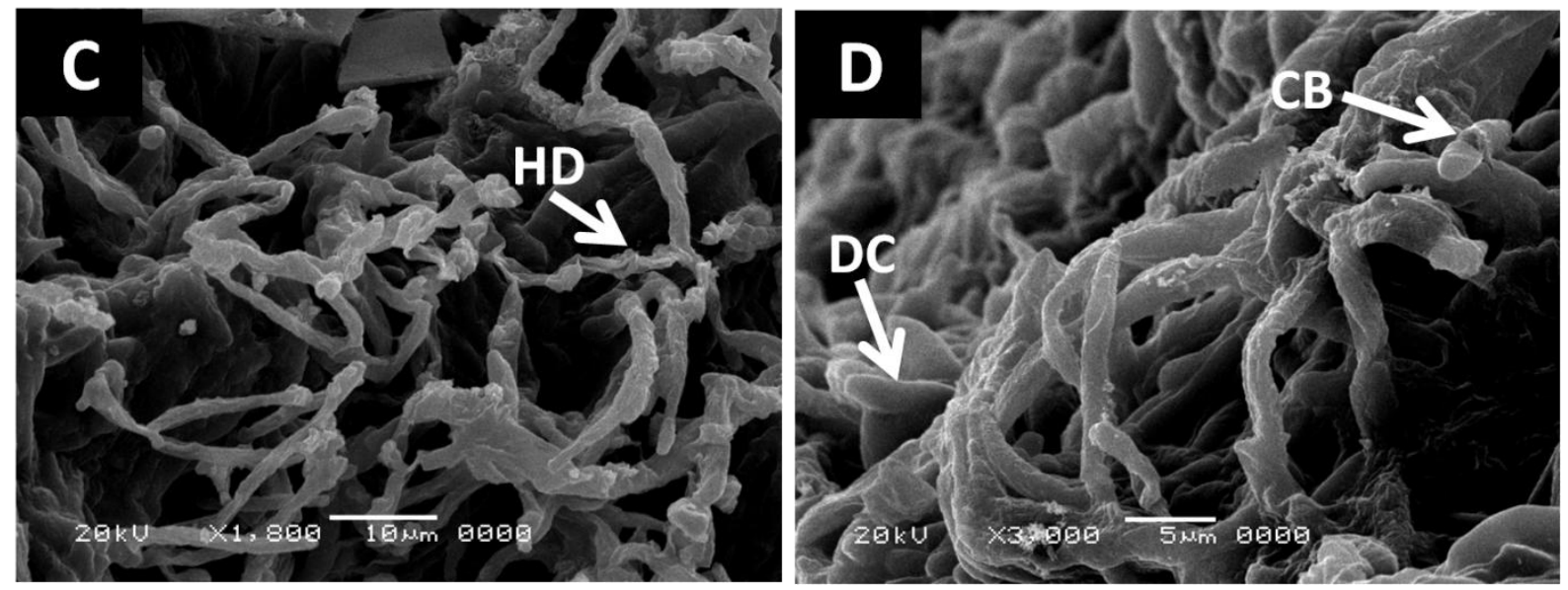

Photo4(A, B, C and D) - SEM Micrographs of F. oxysporumat x1800,x2300, x2500 and x3000. In untreated culture, photo 4(A) Showing uniseriate and uniform hypha (H) with macro (MA) and micro conidia (MI). Photo 4 (B, C and D) - SEM Micrographs of $F$. oxysporum co-cultured with treatmentShowing hyphal disruption and break down (HD)Photo 4(B and C) with macro and micro conidia were deformed (DC) and broken down (CB)Photo 4(D) partially with reduced number Photo 4(B, C andD respectively) in comparison with control Photo 4 (A).

SEM examinations of $F$. oxysporum also showed varied morphological changes between treated and untreated mycelia; control $F$. oxysporum hyphae $(\mathrm{H})$ are smooth surface, uniseriate and uniform bearing macro (MA) and microconidia (MI) as illustrated in Photo. 4(A).

AR compost tea+OP+MO treatment altered the morphology and conidia of $F$. oxysporum $\mathrm{f}$. sp. lentis; in Photo 4(B, C and D)the mycelium appeared distorted (HD), showing extreme shrinkage, shriveling, with discontinuous areas due to the effect of hyphae breaking Photo. 4 (B and C) and cytoplasmic loss when compared with hyphae grown in control. Furthermore, macroconidial shape was greatly distorted (CD), and microconidia were broken (CB) and completely absent. As well as reduction in the amount of conidia was observed.

\section{Discussion:-}

This study focus on biological control approach using compost tea in reducing some diseases pathological occurrence.Efficacy of compost teas and their nutrient content differs from each others, and this may be due to the differences in procedures used for preparation of compost teas, the source, nutrient composition, quality and maturity of the compost (Al-Dahmani et al., 2003).

The $\mathrm{pH}$ values of the four tested compost tea (6.92-8.05) were within the range suitable for compost tea preparation (Bord na Mona, 2003).Adegun loye et al. (2007) reported that most of the microorganisms in compost best survived under neutral $\mathrm{pH}$. The increase in $\mathrm{pH}$ is likely due to an overall uptake of more anions than cations by the microbiota (Yan et al., 1996). With respect to $\mathrm{EC}$, our results for $\mathrm{AR}$ and $\mathrm{AR}+\mathrm{OP}$ compost tea recorded $2.50 \mathrm{ds} / \mathrm{m}$ and $3.30 \mathrm{ds} / \mathrm{m}$ respectively, both were within the range from $0-3.5 \mathrm{ds} / \mathrm{m}$ which is acceptable for general crop 
growth (Rynk et al., 1992), while MSW and MSW+OP compost teas have higher EC values recording6.62 ds/m and $6.33 \mathrm{ds} / \mathrm{m}$ respectively, which may be due to excess salt concentration which might hinder plant growth by affecting the soil-water balance. Lasaridi et al. (2006) proposed that value $4.0 \mathrm{ds} / \mathrm{m}$ for EC is a level considered tolerable by plants whereas values from 6 to $12 \mathrm{ds} / \mathrm{m}$ indicating toxicity due to salts for most plants up to Greek standards.

Concerning macro and micronutrients, our results shows that all compost teas contain a considerable amount of nutrients. Chemical properties are very important factor in determining the value of the produced compost tea (Hegazy et al., 2015). Enriched compost teas showed high characters than the unenriched types.

The ratio of optical density at $465 \mathrm{~nm} / 665 \mathrm{~nm}\left(\mathrm{E}_{4} / \mathrm{E}_{6}\right.$ ratio), all values in this study are relatively lower than 5 which indicate a relatively high degree of condensation of aromatic humic constitutes (HA's) (Pare et al., 1997), and showed that all compost teas are characterized with humic acids more than fulvic acids which in turn indicate enhanced humification. These results are similar to those obtained by (Claus et al., 1999).

The Microbial levels in all tested compost teas were in the range of $10^{6}$ and $10^{8} \mathrm{cfu} / \mathrm{ml}$ which is consistent with the microbial analysis of liquid biofertilizers produced from different plant-based raw materials during fermentation (Ngampimol \& Kunathigan, 2008).

Scheuerell and Mahaffee, (2004); Diánez et al., (2007) have studied the level of microbial population in compost teas necessary to determine their phytopathogens suppressive level. As well as Sylvia (2004) reported that compost extract containing high population of microbiota such as Rhizobacteria, Trichoderma and Pseudomonas spp. induce disease resistance as well as stimulate nutrient uptake, enhanced the growth and yield of crops (Scheuerell and Mahaffee, 2002; Ingham, 2005). It also contains growth hormones and anti-pathonic chemicals such assiderophores tannins and phenols (Antonio et al., 2008), and vitamin C (Ha et al., 2008).

Regarding the recorded Dehydrogenase activity (133.6, 125, 131.8 and $130 \mu \mathrm{g}$ $\mathrm{TPF} / \mathrm{ml} / 24 \mathrm{hrs}$ ) their high values might have been the result of high microbial activity (Benito et al., 2003). The plant biological assay revealed that the four prepared compost teas in the present study were not phytotoxic and suitable for utilization with more than $80 \%$ of germination index (Emino \& Warman, 2004).

Concerning the inhibitory effect of compost teas on the tested fungal pathogens, in vitro assay results revealed that all tested Aerated Compost Teas (ACT) exhibited significant inhibition of mycelia growth of $R$. solaniand $F$. oxysporum in comparison with control.

By enrichment of compost with both Olive Pomace (OP) and Microorganisms (MO), and monitoring their effect againstR.solaniand $F$. oxysporumin vitro; the recorded results showed that compost tea plus OP and MO significantly increased the antifungal activity againstR.solaniand $F$. oxysporumcompared to compost tea alone,. This may be due to the biological interactions between microorganisms, compost and plant products and can be a valuable source of new and 
effective antimicrobial substances, which could affect differently on the microbial pathogens compared to other conventional antimicrobials (Mokhtar et al., 2014). This could be explained by the presence of antagonistic microorganisms either normal inhabitant of compost tea or added; Bio-agents produce biologically active compounds (antibiotics and toxic substances) that have antifungal activity, besides bioactive compounds including plant growth regulators like gibberellin, auxin, cytokinin, ethylene, abscisic acid, jasminc acid, protein, vitamins and minerals (Noble and Coventry, 2005), and active antifungal compound in compost extracts (El-Masry et al., 2002), like OP which cause significant reduction in mycelia growth of the pathogen on PDA. The antifungal effect of OP extract is related to their chemical composition (is attributed mainly to the chemical constituents phenol and oleosidic compounds which has potent antimicrobial properties) (Markin et al., 2003; Pereira et al., 2006; Medina et al., 2009 and Dayan et al., 2009). Phenolic compounds have several mechanisms of antimicrobial effect such as denaturation of enzymes, this is attributed to the presence of phenolic $\mathrm{OH}$ group that are known to be reactive and form hydrogen bonds with - SH groups in the active sites of target enzymes, resulting in deactivation of enzymes in fungi (Furneri et al., 2002; Velluti et al., 2003; Alma et al., 2007), lead to inhibition of spore germination, alter the permeability of the cell wall (William, 2008), bind to substrates such as minerals, vitamins and carbohydrates making them unavailable for microorganisms (Stern et al., 1996; Shahidi \& Naczk, 2004).

Obtained results showed that the fungicide Rhizolex-T inhibited the mycelia growth of $R$. solani $(83.70 \%, 100 \% 100 \%$ and $100 \%)$ and F.oxysporum $(5.80 \%, 12.01 \%, 17.81 \%$ and $37.47 \%$ ) at concentrations $1,5,10$ and $25 \mathrm{ppm}$ respectively. This fungicide is considered very effective against $R$. solanithan $F$. oxysporum. The antifungalRhizolex-T greatly effect on the lipid and membrane synthesis of pathogenic fungi. These results are in agreement with those reported by (Abd El-Aziz, 2007; Karlsson et al., 2014). These results are supported by that of Hameed (2008) who showed that Rhizolex-T completely caused growth inhibition of $R$. solani. Similar results concerning the response of Rhizolex-T at different concentration were also reported by (Abdel-Kadar, 1997, 1999).As revealed by SEM micrographs, morphological distortions in $R$. solani hyphae may be attributed to the occurrence of cell wall injury and/or reduction in fungal cell turgor pressure which have been suggested to be due to alterations in membrane permeability (Rittiwong et al., 2011), resulting in collapse and shrinkage of hyphae and cells (Bi et al., 2006; Li et al., 2009; Liu et al., 2010)..Alterations and damage on vegetative hyphae have been previously described by many workers (Hashem, 2011; Khan and Ahmad, 2011); theyfound thatthe morphological changes might result from the destruction of organelles in the endomembranes system.

Regarding F. oxysporum SEM micrographs, the morphological distortions in hyphae and macroconidia was observed which indicate that this filtrate caused the damage of cell wall, plasma membrane of hyphae, macroconidia and microconidia. This damage may responsible for the growth inhibition of $F$. oxysporum. 
Generally this indicates that $\mathrm{AR}+\mathrm{OP}+\mathrm{MO}$ extract possessed marked antifungal property against both $R$. solani and $F$. oxysporum; primarily affected cell permeability through direct interaction with the cell membrane. A change in cell permeability which might have resulted in an imbalance in intracellular osmotic pressure, subsequent disruption of intracellular organelles, leakage of cytoplasmic contents and finally cell death(Abdel-Monaim et al., 2011;Kagale et al., 2011).

\section{Conclusion:-}

These results demonstrated that compost teas enriched with OP and bioagents mixture are suitable products for in vitro suppression of some phytopathogenic fungi and thus could reduce the need of the fungicide use. The disposal of OP represents a challenge for the environment, although it might also be an opportunity; this study addressed the use of low amounts of OP wastes, which can be used to counteract the effects of some soil-borne pathogenic fungi in agriculture. Successful development of such compounds as antifungal would not only provide a potent tool for control of lentil root-rot and wilt, but also could promise success in multipurpose biorational alternatives to conventional fungicides for the management of other plant diseases. This effective, environmental friendly and human safety products has much potential.

\section{References:-}

Abd El-Aziz, A.S. (2007). Studies on Verticillium wilt of olive in Egypt. Ph.D. Thesis Fac. Agric., Ain Shams Univ. 224 pp.

Abdel-Kader, M. M.(1997).Field application of Trichoderma harzianum as biocidefor control bean root rot disease.Egypt. J. Phytopathol., 25: 19-25.

Abdel-Kader, M.M. (1999).Biological and chemical control of wilt disease of hotpepper (Capsicum annum L.).Egypt. J. Phytopathol., 27:1-8.

Abdel-Monaim M F, Abo-Elyousr K A, Morsy K M. (2011). Effectiveness of plant extracts on suppression of damping-off and wilt Diseases of lupine (Lupinus termis Forsik) Crop Prot. 30: 185-191.

Abdel-Wahab, A.F.M. (2008).Evaluation of Enriched Compost and its Role in Synergy with Rhizobacteria and N- fertilization for improving Maize Productivity in sandy soil. J. Agric. Sci., 16(2): 319-334.

Abu-Zreig, M., and Al-Widyan, M. (2002).“Influence of olive mills solid waste on soil hydraulic properties,” Commun. Soil Sci. Plant Anal. 33, 505-517.

Adegunloye, D.V., F.C. Adetuyi, F.A. Akinyosoye and M.O. Doyeni, (2007).Microbial analysis of compost using cowdung as booster.Pakistan J. Nutr., 6: 506-510. 
Agarwal, T., Malhotra, A. and Trivedi, P.C. (2001).Fungi associated with chickpea, lentil and black gram seeds of Rajasthan. Int. J. of Pharma. Biol. Sci., 2(4):478-483.

Al-Dahmani JH, Abbasi PA, Miller SA, Hoitink HAJ (2003). Suppression of bacterial spot of tomato with foliar sprays of compost extracts under greenhouse and field conditions. Plant Dis.; 87:913-919.

Alma M.H., Ertaş M., Nitz S., Kollmannsberger H. (2007). Chemical composition and content of essential oil from the bud of cultivated Turkish clove (Syzygium aromaticum L.).

BioResources 2 (2): 265-269.

Antonio, G.F., Carlos, C.R., Reiner, R.R., Miguel, A.A., Angela, O. L. M. Cruz, M.J.G. and Dendooven, L. (2008).Formulation of a liquid fertilizer for sorghum (Sorghum bicolour (L.)Moench) using vermicompost leachate.Bioresour.Technol. 99, 6174-6180.

Askew D.J., Laing M.D. (1993).An adapted selective medium for the quantitative isolation of Trichoderma species.Plant Pathol. 42 (5): 686-690.

Atlas, R.M. (1995).Handbook of Media for Environmental Microbiology.Boca Raton, Florida, USA, CRC Press.

Baydar, N.G., Sagdic, O., Ozkan, G., Cetin. S., (2006). Determination of antibacterial effects and total phenolic contents of grape (Vitis vinifera) seed extracts. International. Journal of Food Science 41, 799-804.

Benito, M.: A. Masaguer; A. Moliner; N. Arrigo and R.M. Palma (2003).Chemical and microbiological parameters for the characterization of the stability and maturity of pruning waste compost. Springer-Verlag.Biology and Fertility of Soils.Published online: February 22.

Bess, V.H. (2000).Understanding compost tea. BioCycle, 41, 71-72.

Bi, Y., Tian, S.P., Guo, Y.R., Ge, Y.H. and Qin, G.Z. (2006).Sodium silicate reduces postharvest decay on Hami melons: induce resistance and fungistatic effects. Plant Disease 90:279-283.

BonanomiG., Giorgi V., Del Sorbo G., Neri D., Scala F. (2006). Olive mill residues affect saprophytic growth and disease incidence of foliar and soilborne plant fungal pathogens. Agric Ecosyst Environ. 115, 194-200.

Bord na Mona (2003).Compost Testing And Analysis Service - Interpretation of Results, available from Bord na Mona, Dublin City Council St Anne's Park ,Newbridge, Co. Kildare, REPORT NO: GW 62, pp. 1-8. 
Bruno, G., Sparapano. L., (2007).Effects of three esca-associated fungi on Vitis vinifera L:V. Changes in the chemical and biological profile of xylem sap from diseased cv. Sangiovese vines. Physiology Molecular Plant Pathology 71, 210-229.

Casida, L.E.; Jr.; D.A. Klein and T. Santoro (1964).Soil dehydrogenase activity. Soil Sci. 98: 371-376.

Castaño R, Borrero C, Avilés M (2011) Organic matter fractions by SP-MAS

Castano, R., Borrero, C. and Aveles, M. (2011). Organic matter fractions by SP-MAS 13C NMR and microbial communities involved in the suppression of Fusarium wilt in organic growth media. Biological control 58: 286 - 293.

Claus, H.; G. Gleixner, and Z. Filip (1999).Formation of humic-like substances in mixed and pure cultures of aquatic microorganisms.Acta Hydrochim.Hydrobiol. 27:200-207.

Dayan, F.E., Cantrell, C.L., \& Duke, S.O. (2009). Natural products in crop protection. Bioorganic and Medicinal Chemistry, 17, 4022- 4034.

Dia'nez F, Santos M, Tello JC (2007).Suppressive effects of grape marc compost on phytopathogenic oomycetes. Arch Phytopathology Plant Protect 40:1-18.

Diánez, F., Santos, M. and Tello, J. C. (2007).Suppressive effects of grape marc compost on phytopathogenic oomycetes. Arch. Phytopathology Plant Protect. 40:1-18.

Diánez, F., Santos, M., Boix, A., de Cara, M., Trillas, I., Avilés, M. and Tello, J.C. (2006). Grape marc compost tea suppressiveness to plant pathogenic fungi: Role of siderophores. Compost Sci. Util., 14: 48-53.

Difco Manual (1984).Dehydrated Culture Media and Reagents for Microbiology. $10^{\text {th }}$ Edition.Difico Laboratories, Detroit, Michigan, USA.

Duggan, T. (2015). Effects of vermicomposted spent mushroom compost on growing medium characteristics, plant growth, yield and abiotic stress tolerance. PhD Thesis, University College Cork.

Elad, Y., Chet, I., Boyle, P., and Henis, Y. (1983).Parasitism of Trichoderma spp. on Rhizoctonia solaniand sclerotium rolfsii-Scanning Electron Microscopy and Flourescence Microscopy. Physiology and Biochemistry, vol. 73, No. 1, pp. 85-88.

El-Hassan S.A. (2004). Biological control of vascular wilt of lentil (Fusarium oxysporum f. sp. lentis) by Bacillus subtilis and Trichoderma hamatum.PhD thesis, The University of Reading, Berkshire, UK, 220 pp. 
El-Masry, M.H., Khalil, A.I., Hassouna, M.S. and Ibrahim, H.A.H (2002).In situ and in vitro suppressive effect of agricultural composts and their water extracts on some phytopathogenic fungi. World J. Microbiol.Biotechnol., 18: 551-8.

El-Mohamedy, R.S.R., Ali, A.H., Mahmoud, A.R., Shafeek, M.R. and Rizk, F.A.(2015).Biocompost field application to control major soil borne fungal diseases and improvement growth and yield of potato (Solanum tuberosum L.) plants. Merit Research Journals, vol.3 (9), pp.139148.

El-Morsi, M.E.A., and Abdel-Monaim, M.F. (2015). Effect of bio-agents on pathogenic fungi associated with roots of some deciduous fruit transplants and growth parameters in New Valley Governorate, Egypt. Journal of Plant Protection Research Vol. 55, No. 2.126-135.

Emino, E. R. and P. R. Warman (2004). Biological assay for compost quality. Compost Science \& Utilization, 12 (4):342-348.

Ergu, F.E., S. Sargin, G. Ngen and F.V. Sukan, (2008).Dephenolisation of olive oil wastewater using adabted Trametes versicolor. International Biodeterioration and Biodegradation, 3: 1-6.

Furneri, P.M., Marino, A., Saija, A., Uccella, N., and Bisignano, G. (2002).In vitro antimycoplasmal activity of oleuropein. Int. J. Antimicrob. Agents, 20(4):293-296.

Gomez, K.A. and Gomez, A.A. (1984).Statistical procedures for Agricultural Research. $2^{\text {nd }}$ ed. Wiley-Interscience Publication.New York.680pp.

Ha, K.V., Marschner, P. and Bunemann, E.K. (2008). Dynamics of C, N, P and microbial community composition in particulate soil organic matter during residue decomposition. Pl. Soil, 303, 253-264.

Hameed , F. E..(2008). Effect of Rizolex on Rhizoctonia solani Kuhn isolates and biocontrol fungus Trichoderma harzianum Rifai in vitro. Journal of the University of Karbala.4:218-223.

Hargreaves, J.C., Adla, M.S., Warman, P.R., (2008). Are compost teas an effective nutrient amendment in the cultivation of strawberries? Soil and plant tissue effects. J Sci Food Agric 89, 390-397.

Hashem, M., (2011).Antifungal properties of crude extracts of five Egyptian medicinal plants against dermatophytes and emerging fungi. Mycopathologia 172, 37-46.

Hegazy MI, Hussein EI, Ali AS (2015).Improving physiochemical and microbiological quality of compost tea using different treatments during extraction. Afr J Microbiol Res 9:763-770.

Hoitink, H.A J. and Boehm, M., (1999). Biocontrol within the context of soil microbial communities: A substrate-dependent phenomenon. Annu. Rev. Phytopathol. 37:427-446. 
Ingham ER (2005). The compost tea.Brewing manual; latest methods and research, 5th edn. Soil Foodweb Incorporated, Corvallis, p 79.

Jimenez, E.I. and V.P. Garcia (1989). Evaluation of city refuses compost maturity: a review. Biol. Wastes 27: 115-142.

Joshi, D., Hooda,K., Bhatt, J., Mina, B. and Gupta, H. (2009).Suppressive effects of composts on soil-borne and foliar diseases of French bean in the fi eld in the western Indian Himalayas. Crop Protection 28, 608-615.

Kagale, S., Marimuthu, T., Kagale, J., Thayumanavan, B., Samiyappan, R., (2011).Induction of systemic resistance in rice by leaf extracts of Zizyphus jujuba and Ipomoea carnea against Rhizoctonia solani. Plant Signal.Behav. 6, 919-923.

Karlsson, I., Friberg, H., Steinberg, C.and Persson, P. (2014).Fungicide Effects on fungal community composition in the wheat phyllosphere. PloS One, v9(11):e111786.

Khalil, I and El-Maghrabia, K (2010). Biological control of Fusarium dry rot and other potato tuber diseases using Pseudomonanas Fluorescens and Enterobacter cloacae Biological Control 53(3) : 280-284.

Khan, M.S.A., Ahmad, I., (2011).In vitro antifungal, anti-elastase and anti-keratinase activity of essential oils of Cinnamomum-, Syzygium- and Cymbopogon-species against Aspergillus fumigatus and Trichophyton rubrum. Phytomedicine 19, 48-55.

Lasaridi K.; I. Protopapa; M. Kotsou; G. Pilidis; T. Manios and A. Kyriacou. (2006). Quality assessment of composts in the Greekmarket: The need for standards and quality assurance. J. of Environ. Management, 80:58-65.

Li, Y.C., Bi, Y., Ge, Y.H., Sun, X.J. and Wang, Y. (2009) Antifungal Activity of Sodium Silicate on Fusarium sulphureum and Its Effect on Dry Rot of Potato Tubers. Journal of Food Science 74(5):213-218.

Litterick A, Harrier L, Wallance P, Watson CA, Wood M. (2004). The role of uncomposted materials, composts, manures and compost extracts in reducing pest and disease incidence and severity in sustainable temperate agricultural and horticultural crop production- a review. Plant Sci., 23:453-479.

Liu, J., Zong, Y., Qin, G., Li, B. and Tian, S. (2010) Plasma Membrane Damage Contributes to Antifungal Activity of Silicon against Penicillium digitatum. Current Microbiology 61: 274-279.

Mahmoud ,S.M.M. (2000).Causes failure of local biocontrol for control cotton seedling disease caused by Rhizoctonia solani (AG4) .Seventh Arabic Conferanc for Science of Plant Protection. 22-26 October Amman,Jurdan. 
Markin, D., Duek, L., \& Berdicevsky, I. (2003). In vitro antimicrobial activity of olive leaves. Mycoses, 46(3-4), 132-136.

Medina, E., García, A., Romero, C., de Castro, A., \& Brenes, M. (2009).Study of the antilactic acid bacteria compounds in table olives. International Journal of Food Science and Technology, 44, pp.1286-1291.

Milinkovic, M., Radic, D., Lalevic, B., Curguz, V.G., Ljubinko, J. L., Ivana, S.I., and Vera, R.V. (2012). Influence of compost tea on inhibition of growth of phytopathogenic fungi Fusarium oxysporum and Rhizoctonia sp. Inst. Plant Protec. Environ., pp.317-320.

Mokhtar, M.M., El-Mougy, N.S., Abdel-Kareem, F., El-Gamaal, N.G. and Fatouh, Y.O. (2014).Effect of some botanical powdered plants against root rot disease incidence of bean under field conditions. Int. J. Enginee. Innov.Technol., 4(1):162-167.

Naidu, Y., Meon, S., Kadir, J. and Siddiqui, Y. (2010).Microbial starter for the enhancement of biological activity of compost tea. Int. J. Agric. Biol., 12: 51-6.

Ngampimol, H. and V. Kunathigan, (2008). The study of shelf life for liquid biofertilizers from vegetable waste. Assumption Univ. J. Technol., 11: 204-208.

Noble, R. and Coventry, E. (2005). Suppression of soil-borne plant diseases with composts: A Review. Biocon. Sci. Technol., 15:3-20.

Okoth, S.A., H. Roimen, B. Mutsotso, E. Muya, J. Kahindi, J.O. Owino and P. Okoth, (2007). Land use systems and distribution of Trichoderma species in Embu Region, Kenya. Tropic.Subtropic.Agroecosyst., 7: 105-122.

Page, A.L., R.H. Miller and D.R. Keeney (1982).Methods of Soil Analysis .II, Chemical and Microbiological Properties $2^{\text {nd }}$ Ed. Madison Wisconsin, USA.

Pane C, Celano G, Villecco D, Zaccardelli M (2012). Control of Botrytis cinerea, Alternaria alternata and Pyrenochaeta lycopersici on tomato with whey compost-tea applications. Crop Prot $38: 80-86$.

Pant, A., Radovich, T.J.K., Hue, N.V., Talcott, S.T., Krenek, K.A., (2009). Vermicompost extracts influence growth, mineral nutrients, phytonutrients and antioxidant activity in Pak choi (Brassica rapa cv. Bonsai, Chinensis group) grown under vermicompost and chemical fertilizer. J Sci Food Agric 89, 2383-2392.

Pare, T.; E.G. Gregorich and H. Dinel (1997). Effects of stockpiled and composted manures on germination and initial growth of cress (Lepidium stavium). Biological Agric. \& Hort., 14: 52-65. 
Pereira, J. A., Pereira, A. P., Ferreira, I. C., Valentão, P., Andrade, P. B., Seabra, R., Estevinho, L., \& Bento, A. (2006). Table olives from Portugal: phenolic compounds, antioxidant potential, and antimicrobial activity. Journal of Agricultural and Food Chemistry, 54(22), 8425-8431.

Perveen K, Bokhari NA (2012). Antagonistic activity of Trichodermaharzianum and Trichodermaviride isolated from soil of date palm field against Fusariumoxysporum. Afr. J. Microbiol. Res. 6 (13):3348-3353.

Rittiwong, T., Mutarapat, T., Ponglimanont, C., Mahabusarakam, W., Chakthong, S., (2011). Saiyutones A-D: four new unusual biflavones from Desmos chinensis. Tetrahedron 67, 5444-5449.

Rynk, R., M. Van De Kamp, G.G. Willson, M.E. Singley, T.L. Richard, J.J. Kolega, F.R. Gouin, L. Laliberty Jr., D. Kay, D. Murphy, H.A.J. Hoitink and W.F. Brinton, (1992).Onfarm composting handbook. In: Rynk, R. (ed.), NRAES-54. Natural Resource, Agriculture and Engineering Service, Ithaca, New York, USA.

Scheuerell, S. J. and Mahaffee, W. F. (2002). Compost tea principals and prospects for plant disease control. Compost Sci. Util. 10:313-338.

Scheuerell, S.J. and W.F. Mahaffee,(2004).Compost tea as a container medium drench for suppressing seedling damping-off caused by Pythium ultimum.Phytopatho., 94: 1156-1163.

Shahidi, F. and Naczk, M. (2004).Phenolics in food and nutraceuticals. Boca Raton, FL: CRC Press. Pp.352-355.

Singelton, V.L. and Dwivedi, R.S. (1987).Effect of oils on Sclerotium rolfsii causing foot-rot of barley. Ind. Phytopathol., 40: 531-533.

Singelton, V.L. and Rossi, J.A. (1965).Colorimetry a total Phenolics with phosphomolibdicphosphotungstic acid reagents. Amer. J. Enol. Vitic., 16:144-158.

Stern, J.L., Hagerman, A.E., Steinberg, P.D. and Mason, P.K. (1996).Phlorotanninprotein interactions. Chem. Ecol., 22(10):1887-1899.

Sylvia, E.W. (2004). The effect of compost extract on the yield of strawberries and severity of Botrytis cinerea. J. Sustainable Agric., 25(1): 1-8.

Velluti A., Sanchis V., Ramos A.J., Egido J., Marln S. (2003). Inhibitory effect of cinnamon, clove, lemongrass, oregano and palmarose essential oils on growth and fumonisin B1 production by Fusarium proliferatum in maize grain. J. Food Microbiol. 89: 145-154. 
William, Q. (2008).Least toxic controls of plant diseases.Brooklyn Botanic garden. Natural Disease Controls, 11:225.

Yan, F., Schubert, S., and Mengel, K. (1996).Soil pH increasedue to biological decarboxylation of organic anions. Soil Biol. Biochem.28, 17-24.

Yang L., Wang Y. J., Song J., Zhao W., He X. L., Chen J., et al. (2011). Promotion of plant growth and in situ degradation of phenol by an engineered Pseudomonas fluorescens strain in different contaminated environments. Soil Biol. Biochem. 43, 915-922.

Yogeu A; Raviv M; Hadar Y Cohen R and Katan J. (2006). Plant waste based composts suppressive to diseases caused by pathogenic Fusarium oxysporum . Eur. J. Plant Pathology 116:267-276.

Zaccardelli, M., Perrone, D., Pane, C., Pucci, N. and Infantino, A. (2011).Control of corky root of tomato with com post and role of spore-forming bacteria to inhibit Pyrenochaeta lycopersici. Acta Horticulturae (ISHS) 914, 393-396.

Zhao Q, Dong C, Yang X, Mei X, Ran W, Shen Q, (2011). Biocontrol of Fusarium wilt disease for Cucumis melo using bio-organic fertilizer. Appl Soil Ecol. 47: 67-75.

Zhao, S., Lian, F., Duo, L. (2011): EDTA-assisted phytoextraction of heavy metals by turfgrass from municipal solid waste compost using permeable barriers and associated potential leaching risk. Bioresource Tech. 102, 621-626. Zhao, S., Lian, F., Duo, L. (2011): EDTA-assisted phytoextraction of heavy metals by turfgrass from municipal solid waste compost using permeable barriers and associated potential leaching risk. Bioresource Tech. 102, 621-626. Zhao, S., Lian, F., Duo, L. (2011): EDTA-assisted phytoextraction of heavy metals by turfgrass from municipal solid waste compost using permeable barriers and associated potential leaching risk. Bioresource Tech. 102, 621-626. Huang et al. (2011) Huang XQ, Chen LH, Ran W, Shen QR, Yang XM. Trichoderma harzianum strain SQR-T37 and its bio-organic fertilizer could control Rhizoctonia solani damping-off disease in cucumber seedlings mainly by the mycoparasitism. Applied Microbiology and Biotechnology. 2011;91:741-755. Huang et al. (2011) Huang XQ, Chen LH, Ran W, Shen QR, Yang XM. Trichoderma harzianum strain SQRT37 and its bio-organic fertilizer could control Rhizoctonia solani damping-off disease in cucumber seedlings mainly by the mycoparasitism. Applied Microbiology and Biotechnology. 2011;91:741-755. Huang et al. (2011) Huang XQ, Chen LH, Ran W, Shen QR, Yang XM. Trichoderma harzianum strain SQR-T37 and its bio-organic fertilizer could control Rhizoctonia solani damping-off disease in cucumber seedlings mainly by the mycoparasitism. Applied Microbiology and Biotec Huang et al. (2011) Huang XQ, Chen LH, Ran W, Shen QR, Yang XM. Trichoderma harzianum strain SQR-T37 and its bio-organic fertilizer could control Rhizoctonia solani damping-off disease in cucumber seedlings mainly by the mycoparasitism. Applied Microbiology and Biotechnology. 2011;91:741755.hnology. 2011;91:741-755. 
Znaidi, I.A., (2002).Study and evaluation of composting of different kinds of organic matter and the effects of organic compost teas on plant diseases.Master. Sci. Agron., Inst. Agron. Medit., Bari, Italie, pp: 94.

\section{الملخص باللغة العربية}

التأثير المختبري لشاى الكمبوست المحضر من المخلفات الزراعية ونفايات البلديات الصلبة على بعض الفطريات الممرضة من المخات

جيهان عبد المنعم الباز 1 سامية حسن أبوذكرى²، إيهاب على ضياء محمد سرحان3، مهرشان طه المقدم

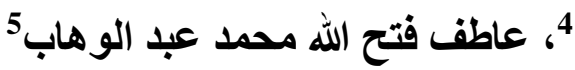

4,2,1 قسم النبات، كلية البنات للاداب و العلوم و التربية، جامعة عين شمس

3 معهد بحوث امر اض النبات ، مركز البحوث الزر اعية، الجيزة، مصر

5 قسم الميكروبيولو جيا الزر اعية، معهد بحوث الأر اضى و المياه و البيئة، مركز البحوث الزر اعية، الجيزة، مصر

تم تجعيز مستخلص هو ائى لثناى الكمبوست من اربع انو اع مختلفة من الكمبوست الصلب من المخلفات

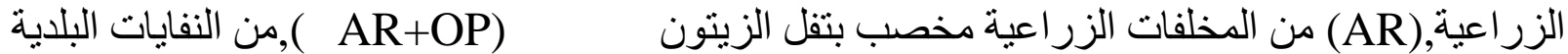
الصلبه, (MSW) من النفايات البلدية الصلبه المخصب بتفل الزيتون (MSW+OP), و تم توصيفهم تحليليا ثم اختبار النشاط العدائى لكل منهم فى المختبر أما بمفردهم أو مع اضافة خليط من الكائنات ذات النشاط

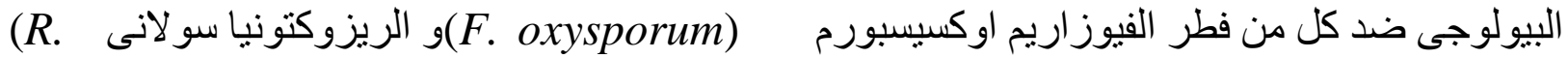
بالمقارنة solani)

تم فحص العينة الاكثر تاثير ا بالمجهر الالكترونى لثرح طريقة عملها فى المكافحة البيولوجية ضد المسبب في فئه

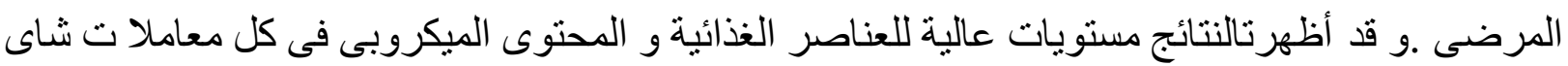

الكمبوست.اعطت المعاملات المختلطةأعلى نسبة تثبيط مقارنة بالمعاملات الاخرى ضد كل من الفطريين الممرضين , حيث اظهرت نسبة 63,52\% و 44,07\% في حاله استخدام كمبوست المخلفات الزر اعية المخصب بتفل الزيتون و كائنات الدقيقة ذات النشاط الحيوى(AR+OP+MO) و 57,41 \% \% حاله كمبوست المخلفات الصلبه المخصب بتفل الزيتون و الكائنات الدقيقة ذات النشاط الحيوى الريزوكتونيا سو لانى و الفيوزاريم اوكسيسبورم على التوالى . اظهرت نتائج الفحص (MSW+OP+MO)

الالكترونى للخيوط الفطرية للعامل الممرض التى تم از التها من منطقة المو اجهة حدوث تغير مورفولونيا لونيا

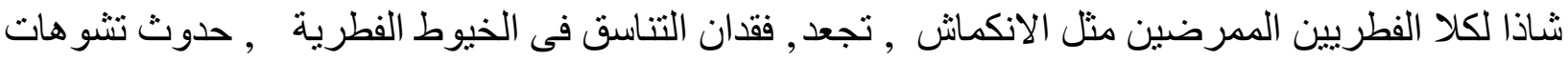
جزئية و تحلل.،تقدم هذها لنتائج دليلا على أن هذا المستخلص لها لقدرة على أن يصبح مرشحًا جيدًا للسيطرة البيولوجية كبدائل محتملة لتطبيق العبيدات الفطرية الاصطناعية، وكمحفز نباتث في إنتاج المحاصبل، لتحقيق الاستدامة البيئية وسلامة الأغذية. 